\title{
Obstetric and new born outcome in HIV infected pregnant women: a prospective cohort study in Bangalore Medical College Hospitals, India
}

\author{
Rashmi S. Desai ${ }^{1}$, Geetha Shivamurthy ${ }^{2}$, Sameer Desai $^{3 *}$
}

\author{
${ }^{1}$ Department of Obstetrics and Gynecology, KIMS, Hubli, Karnataka, India \\ ${ }^{2}$ Department of Obstetrics and Gynecology, BMCRI, Bangalore, Karnataka, India \\ ${ }^{3}$ Department of Obstetrics and Gynecology, Anaesthesiology, SDM CMS and H, Sattur, Dharwad, Karnataka, India
}

Received: 17 August 2018

Accepted: 27 September 2018

\author{
*Correspondence: \\ Dr. Sameer Desai, \\ E-mail: sameeranaes@gmail.com
}

Copyright: (c) the author(s), publisher and licensee Medip Academy. This is an open-access article distributed under the terms of the Creative Commons Attribution Non-Commercial License, which permits unrestricted non-commercial use, distribution, and reproduction in any medium, provided the original work is properly cited.

\section{ABSTRACT}

Background: The effect of HIV on obstetric complications is known to vary across regions of world. The variation may be due to HIV infection per se or it may be due to complex interaction of related medical and social conditions that affect pregnancy. Incidence of these obstetric complications in HIV infected pregnant women is not well reported in India. So, this prospective cohort study was carried to observe the demographics and incidence of obstetrics complications like abortions, still birth, premature rupture of membranes, preterm delivery, opportunistic infections in HIV infected pregnant women.

Methods: All pregnant women who were screened positive for HIV test, irrespective of their gestational age were included in the study. Apart from routine obstetric care, CD4 cell count was carried out. The patients were followed up till term, delivery and up to 6-week postpartum period. Obstetric outcomes like incidence of abortion, intrauterine death, preterm delivery and premature rupture of membrane were noted. Baby`s birth weight and the incidence of maternal opportunistic infection were noted and correlated with maternal CD4 cell count.

Results: Maternal HIV infection is associated pre-term labour in 34.5\%, PROM in 30\%, low birth weight in $52.3 \%$. Increased incidences of these adverse outcomes have an inverse relationship with CD4 count.

Conclusions: Maternal HIV infection is associated with increased incidence of adverse obstetric outcome and opportunistic infection, and their incidences increase with lower CD4 count.

Keywords: CD4 T cell, Low birth weight, Maternal HIV infection, Obstetric complications, Preterm labour, PROM

\section{INTRODUCTION}

In 2009 it was estimated that 2.4 million people were living with HIV in India, which equates to a prevalence of $0.3 \% .^{1}$ India had the third highest number of people living with HIV. Women are among the fastest growing populations getting infected with HIV and AIDS and most of them are in childbearing age. ${ }^{1}$ With the early detection and increasing use of antiretroviral therapy, more number of HIV positive women are entering family cycle and are delivering. HIV infection has been reported to have little effect on pregnancy outcome or complications in the developed world. ${ }^{2,3}$ Adverse pregnancy outcomes have, however, been reported more commonly in a number of African studies. ${ }^{4-7}$ It is often difficult to determine the relative contribution of HIV infection, drug abuse and inadequate antenatal care to adverse outcomes in these women. ${ }^{8,9}$ Thus the adverse pregnancy outcome in HIV may directly by HIV infection or it may be a marker of a complex interaction of related medical and social conditions in that community. But the effects of HIV infection on maternal 
morbidity, obstetric complications are not well reported in India. So, this prospective cohort study was carried out to observe the demographics and obstetrics complications in HIV infected pregnant women.

\section{METHODS}

This hospital based prospective cohort study was carried out after taking approval from the institutional ethics committee. The study was carried out in the antenatal clinics of the two tertiary referral hospitals of Bangalore medical college and research institute; namely Vani Vilas hospital and Bowring and Lady Curzon Hospital, Bangalore. All the pregnant women attending the antenatal clinic at the above-mentioned hospitals from November 2009 to November 2010 were screened for HIV infection. Diagnosis of HIV infection was made as per the NACO guidelines, using rapid ELISA tests. ${ }^{10}$ Those patients, who were found to be seropositive for HIV, underwent post-test counselling.

\section{Inclusion criteria}

All pregnant women who were screened positive for HIV test, irrespective of their gestational age and irrespective of whether they received any antiretroviral treatment (ART), were included in this study.

\section{Exclusion criteria}

Those HIV seropositive pregnant women who had other pre-existing chronic medical conditions like cardiac disease, diabetes mellitus, chronic renal failure and chronic liver disease were excluded, since these medical conditions are known to independently affect the pregnancy outcome.

Informed consent was obtained from all the HIV positive pregnant women to be part of this study. Pregnant women were given routine antenatal care including history, clinical examination. Routine antenatal investigations were done which included: complete haemogram, blood grouping and $\mathrm{Rh}$ typing, urine routine and microscopy, random blood sugar, serum for Hepatitis B antigen and VDRL.

The patients underwent obstetric ultrasound scan as needed. Once they were counselled about the HIV status, their sexual history, including history of multiple sexual partners by the woman herself and her partner was taken. Other high-risk factors for HIV transmission like blood transfusion or intravenous drug abuse were also noted.

Histories of other sexually transmitted diseases were noted and if present, they were treated. The parturient were explained the possibility of mother- to-child HIV transmission, the available methods to reduce the transmission rate and the facilities available for the follow up of the infants. If the pregnancy was within 20 weeks of gestation, then the option of termination of pregnancy was offered. Those desirous of continuing the pregnancy were followed up.

Based on the CD4 count and WHO stage of the disease, pregnant women were considered for ART at the earliest after detection. They were given ART as per NACO guideline 2007. ${ }^{11}$ The neonate received a single dose of 2 mg per $\mathrm{kg}$ body weight of syrup Nevirepine within 72 hours of delivery and it was continued daily for 6 weeks. The parturient, who requested for elective lower segment caesarean section (LSCS) to reduce the risk of mother-tochild HIV transmission, were offered LSCS. Other parturient had either normal vaginal delivery or LSCS as per the obstetric indication. All women received 5-day course of antibiotics with first generation cephalosporin, irrespective of whether it was vaginal delivery or LSCS.

Demographic data like age of the parturient, their religion, educational status, occupation and occupation of their partner were collected. Obstetric data like number of years of married life, obstetric score, gestational age at the time of delivery, status of membranes at onset of labour, mode of delivery, incidence of postpartum complications like retained placenta, puerperal pyrexia, urinary infection, puerperal sepsis and burst abdomen were noted.

New born birth weight was also noted. Authors wanted to assess whether the severity of HIV infection, as indicated by $\mathrm{CD} 4$ count, affects the incidence of obstetric complications. Hence the patients were categorised based on their CD4 cell count in to those with CD4 cell count more than 350 and those with count less than 350 .

\section{Statistical analysis}

SPSS version 16 was used for analysing the data. Before analysis, the data was checked for consistency in range. Categorical data like obstetric complications, foetal complications, opportunistic infections were analysed using Chi square test and data is expressed as frequency and percentages. Continuous data like birth weight was analysed by independent sample t-test and expressed as mean and standard deviation.

\section{RESULTS}

A total $120 \mathrm{HIV}$ seropositive pregnant women were followed up prospectively. The pregnant women were aged between 17 to 45 years, with mean age of 24.1 years (Table 1). The majority were detected to be seropositive within 4 years of married life.

(Table 2) Forty per cent of couple agreed to have polygamous relation and $17 \%$ of the women had previous history of blood transfusion. In remaining obvious risk factor for HIV were not available in history. Authors noted $92(77 \%)$ of the husbands were HIV positive and $27(23 \%)$ of the husbands were seronegative. In 1 patient, husband's HIV status could not be ascertained. 
Seventeen per cent of women had some other sexually transmitted diseases and were treated for the same.

Table 1: Demographic characters.

\begin{tabular}{|c|c|c|}
\hline & $\begin{array}{l}\text { Number of } \\
\text { patients, } n=120\end{array}$ & Percentage \\
\hline \multicolumn{3}{|l|}{ Age (years) } \\
\hline $15-19$ & 5 & 4 \\
\hline $20-25$ & 79 & 66 \\
\hline $26-30$ & 29 & 24 \\
\hline$>30$ & 7 & 6 \\
\hline \multicolumn{3}{|l|}{ Religion } \\
\hline Hindu & 98 & 81.6 \\
\hline Muslim & 21 & 17.5 \\
\hline Christian & 1 & 0.8 \\
\hline \multicolumn{3}{|l|}{ Patient education } \\
\hline Illiterate & 62 & 51.6 \\
\hline Primary & 39 & 32.5 \\
\hline Secondary & 17 & 14.1 \\
\hline College & 2 & 1.6 \\
\hline \multicolumn{3}{|l|}{ Husband's education } \\
\hline Illiterate & 42 & 35 \\
\hline Primary & 39 & 32.5 \\
\hline Secondary & 23 & 19.1 \\
\hline College & 16 & 13.3 \\
\hline \multicolumn{3}{|l|}{ Occupation of patient } \\
\hline House wife & 96 & 80 \\
\hline Coolie and farmer & 11 and 4 & 9.1 and 3.3 \\
\hline $\begin{array}{l}\text { Factory and shop } \\
\text { worker }\end{array}$ & 2 and 3 & 1.6 and 2.4 \\
\hline $\begin{array}{l}\text { Commercial sex } \\
\text { worker }\end{array}$ & 2 & 1.6 \\
\hline \multicolumn{3}{|l|}{ Occupation of husband } \\
\hline Driver & 33 & 27.5 \\
\hline Coolie & 28 & 23.3 \\
\hline Factory & 9 & 7.5 \\
\hline Farmer & 19 & 15.8 \\
\hline $\begin{array}{l}\text { Other services (painter, } \\
\text { tailor, cook, mechanic) }\end{array}$ & 19 & 15.8 \\
\hline
\end{tabular}

Pregnant women received ART based on their CD4 count and time of them first reporting to health care system. Twenty-six $(21.6 \%)$ of the women received antiretroviral therapy during the pregnancy and 94 (78.4\%) did not receive antiretroviral therapy. Thirteen of the 120 patients developed opportunistic infection. Opportunistic infections included; Tuberculosis in 3 patients, recurrent urinary infection in 3 , lower respiratory infection with pneumonia in 5, MRSA pneumonia in 1 patient and opportunistic genital ulcer in 1 patient.

Of the $120 \mathrm{HIV}$ positive women in the study, 6 patients had spontaneous abortion, 3 patients opted for termination of pregnancy, 1 patient had septic abortion and 1 patient had an ectopic pregnancy (Figure 1). Remaining 109 patients crossed 28 weeks of gestation and were followed till the delivery for maternal and new born outcome. Eighty-nine $(82 \%)$ of women had vaginal deliveries and 20 (18\%) had LSCS. The vaginal deliveries included 3 forceps assisted deliveries. All of the LSCS were for obstetric reasons and none of women asked for LSCS to reduce the HIV transmission per se. Puerperal pyrexia was seen in 11 (9\%) women, wound infection was noted in 4, puerperal sepsis was seen in 2 women. Burst abdomen and retained placenta were seen in 1 woman each. There were no maternal deaths. The remaining women did not have any complication during puerperium.

Table 2: Obstetric parameter.

\begin{tabular}{|c|c|c|}
\hline & $\begin{array}{l}\text { Number of } \\
\text { patients, } n=120\end{array}$ & Percentage \\
\hline \multicolumn{3}{|l|}{ Married life } \\
\hline$<2$ years & 41 & 34.1 \\
\hline $2-4$ years & 37 & 30.8 \\
\hline$>4$ years & 42 & 35 \\
\hline \multicolumn{3}{|l|}{ Gravida } \\
\hline 1 & 47 & 39.1 \\
\hline 2 & 46 & 38.3 \\
\hline 3 & 22 & 1.1 \\
\hline 4 or more & 5 & 4.1 \\
\hline \multicolumn{3}{|c|}{ Multiple sexual partner } \\
\hline By woman & 5 & 4.1 \\
\hline By husband & 41 & 34.1 \\
\hline Both & 5 & 4.1 \\
\hline None & 69 & 57.5 \\
\hline \multicolumn{3}{|c|}{ Membrane status at labour } \\
\hline Intact & 80 & 73.3 \\
\hline PROM & 29 & 26.6 \\
\hline \multicolumn{3}{|c|}{ Term of delivery } \\
\hline Preterm & 37 & 34.5 \\
\hline Term & 64 & 58 \\
\hline Post-term & 8 & 7.5 \\
\hline
\end{tabular}

There were 5 cases $(4.5 \%)$ of still birth and 5 cases $(4.5 \%)$ with intrauterine death out of 109 births. Hence 99 babies were delivered. Baby weight ranged from 1.0 to $3.75 \mathrm{~kg}$ with the mean birth weight being $2.33 \mathrm{~kg}$. Fifty seven of 99 babies $(57.5 \%)$ had birth weight less than 2.5 $\mathrm{kg}$ and were classified as low birth weight babies.

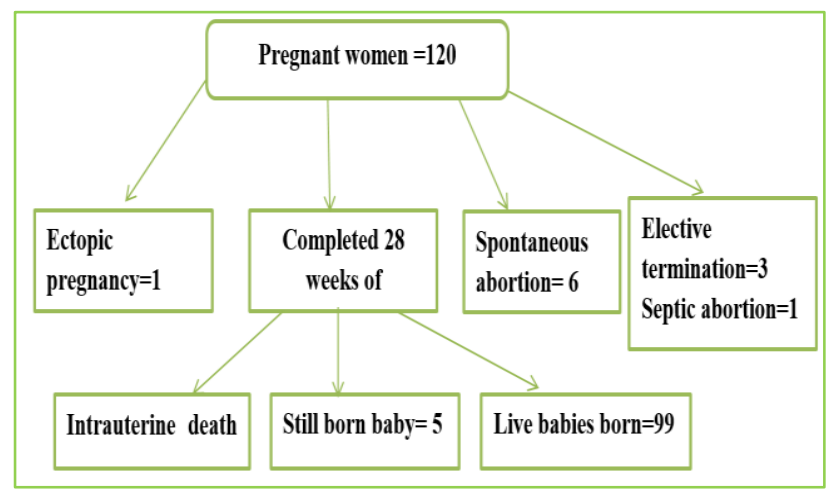

Figure 1: Flow diagram showing number of patients studied. 
Of the 120-total parturient analysed, 39 patients had CD4 count $<350$ and 81 had their CD4 count $>350$ (Table 3). In order to assess whether the obstetric and foetal complications were related to the severity of HIV as depicted by CD4 count, these complications were analysed with low and high CD4 count as two categories. The complications like spontaneous abortions, ectopic pregnancy, preterm labour, PROM, puerperal pyrexia, postoperative wound infection, IUD and still birth were clubbed under obstetric complications. The chances of obstetric complications were significantly higher in patients with low CD4 count than in patients with high CD4 count group (75\% versus $54 \%$ ). The incidence of opportunistic infection was also higher in low CD4 count group than in high CD4 count group. Intrauterine death, still birth and low birth weight, were classified as foetal complications. The incidence of foetal complications were high in those with the low CD4 counts than in high CD4 count group (61\% versus $48 \%)$ But it was statistically not significant.

Table 3: Obstetric complication for all pregnant women.

\begin{tabular}{|c|c|c|c|c|}
\hline Complications & CD4 count $\leq 349(n=39)$ & CD4 count $\geq 350(n=81)$ & Total & \\
\hline Obstetric comp & & & $\mathrm{N}=120$ & \multirow{3}{*}{$\mathrm{p}=0.030$} \\
\hline No & $10(25 \%)$ & $37(46 \%)$ & 47 & \\
\hline Yes & $30(75 \%)$ & $43(54 \%)$ & 73 & \\
\hline \multicolumn{2}{|c|}{ Fetal complications } & \multicolumn{3}{|c|}{$\mathrm{N}=109$} \\
\hline No & $14(39 \%)$ & $38(52 \%)$ & 52 & \multirow{2}{*}{$\mathrm{p}=0.138$} \\
\hline Yes & $22(61 \%)$ & $35(48 \%)$ & 57 & \\
\hline \multicolumn{2}{|c|}{ Opportunistic infections } & \multicolumn{3}{|c|}{$\mathrm{N}=120$} \\
\hline Yes & $8(20 \%)$ & $5(6 \%)$ & 13 & \multirow{2}{*}{$\mathrm{p}=0.022$} \\
\hline No & $32(80 \%)$ & $75(94 \%)$ & 107 & \\
\hline
\end{tabular}

Table 4: Complications in women who crossed 28 weeks of pregnancy.

\begin{tabular}{|c|c|c|c|c|}
\hline Complications & CD4 count $\leq 349(n=35)$ & CD4 count $\geq 350(n=74)$ & $\mathbf{N}=109$ & \\
\hline \multicolumn{5}{|l|}{ Term of delivery } \\
\hline Preterm & $15(43 \%)$ & $22(30 \%)$ & 37 & \multirow{2}{*}{$\mathrm{p}=0.383$} \\
\hline Term & $19(54 \%)$ & $45(60 \%)$ & 64 & \\
\hline Post term & $1(3 \%)$ & $7(9 \%)$ & 8 & \\
\hline \multicolumn{5}{|l|}{ Membrane status } \\
\hline Intact & $25(72 \%)$ & $55(74.3 \%)$ & 80 & \multirow{2}{*}{$\mathrm{p}=0.626$} \\
\hline PROM & $10(28 \%)$ & $19(25.7 \%)$ & 29 & \\
\hline \multicolumn{5}{|l|}{ Birth weight } \\
\hline Low $(<2.5 \mathrm{~kg})$ & $23(65.7 \%)$ & $35(47.3)$ & 58 & \multirow{2}{*}{$\mathrm{p}=0.072$} \\
\hline Normal $(>2.5 \mathrm{~kg})$ & $12(34.3)$ & $39(52.7)$ & 51 & \\
\hline
\end{tabular}

Of the 109 women who crossed 28 weeks of gestation, 35 pregnant women had low CD4 count and 74 women had high CD 4 count (Table 4). Even though the incidences of preterm labour and PROM were higher than in low CD4 count group than high CD4 group, it did not reach statistical significance.

\section{DISCUSSION}

In the present study, majority of women were in the age group of 20 to 25 years, illiterates and had a married life of less than 4years. The study population had $81 \%$ Hindus, $18 \%$ Muslims and less than 1\% Christians. These parameters fairly represent the demographic parameters of Indian city, like Bangalore. Only seven per cent women had history of blood transfusion and none had history of IV drug abuse. Hence sexual route is the most common route of HIV transmission in India. Pattern of seropositivity in husbands confirms the heterosexual mode of transmission as the most common mode. High risk behaviour (polygamous relationship) was observed in $4 \%$ of the patients in contrast to $34 \%$ in husbands and in $4 \%$ in both the partners. In recent years married monogamous women have been identified as a population at increasing risk for HIV in India. In India, drivers and commercial sex workers are already recognised as high risk for HIV infection. Authors noted high incidence in coolies working on daily wages, most of whom are immigrants to city from other villages as other high-risk group. Seventeen per cent of the women in this study group had either previous history or an ongoing presence of STDs. In another study conducted in 
India, 20.7\% HIV positive women had additional STDs compared to only $4.6 \%$ HIV negative women. ${ }^{12}$

Of the $120 \mathrm{HIV}$ positive women in the study, 6 patients had spontaneous abortion and 1 patient had an ectopic pregnancy. HIV infection in Africa has been linked to a higher rate of spontaneous abortion. ${ }^{13}$ In a prospective follow-up American study showed a three-fold increase in early spontaneous abortion. ${ }^{14,15}$ Authors noted incidence of preterm delivery around $34.5 \%$ in the present study, which is slightly higher than reported in other studies in HIV positive women. Temmerman et al reported that prematurity was observed in $21.1 \%$ of neonates born to HIV positive women compared to $9.4 \%$ of those born to HIV negative women. ${ }^{6}$ In other studies in HIV infected women the incidence of premature delivery varied from $14-23 \% .^{16,17}$

The incidence of PROM in the present study was $26.6 \%$. Other studies have observed incidence of PROM varying from $15-50 \% .^{7,12}$ Normal vaginal delivery was the most common route of delivery in the present study and LSCS was carried out only in $18.35 \%$.

Authors noted very high incidence of low birth weight in present patients at $52 \%$. Most of the western studies have reported incidence like $18.9 \%, 19.6 \%$, where incidence of low birth weight in general population is very low. ${ }^{6,16}$ Even other studies from India and Africa have given incidence from 9\%- 22\%. ${ }^{12,18}$ This is still far from $52 \%$ noted in present study. Incidence of low birth weight is known to vary with environmental and many other parameters.

There were 5 still births and 5 IUD out of 109 births. This is higher than incidence seen in normal population. Results are consistent with another large study in Nairobi where it was found that there was increased association between HIV and IUD and still birth rate, after controlling for the presence of other STDs. ${ }^{6}$

Authors noted $17 \%$ incidence of puerperal complications, which was even higher in women who underwent LSCS. These results are consistent with other studies, who have noted higher infectious complications during the postpartum period in HIV-positive women. ${ }^{4}$

Authors noted lower CD4 count is associated with higher incidence of obstetric complications and opportunistic infections. This was statistically as well as clinically significant. The inverse relationship between CD4 count and incidence of opportunistic infections was noted, which is well established fact. Bacterial pneumonia, urinary tract infections and other infections are more common during pregnancy in HIV seropositive women. ${ }^{20}$ The study also showed that lower CD4 count was associated with increased incidence of PROM, Low birth weight, preterm delivery. Though not statistically significant (due to small sample size), it showed that there is trend towards more adverse outcomes with lower CD4 count.

\section{CONCLUSION}

To conclude, maternal HIV infection adversely affects the pregnancy outcome and is significantly associated with higher incidences of obstetric complications and opportunistic infections, more so when the CD4 count is less. HIV infection is also associated with increased incidence of Preterm labour, PROM, low birth weight and postpartum complications and show the increasing trend as the CD4 count decreases.

\section{Funding: No funding sources}

Conflict of interest: None declared

Ethical approval: The study was approved by the Institutional Ethics Committee

\section{REFERENCES}

1. UNAIDS. UNAIDS report on the global AIDS epidemic, 2010. Available at: http://www.unaids.org/globalreport/Global_report.ht $\mathrm{m}$

2. Bakas C, Zarou DM, de Caprariis PJ. First-trimester spontaneous abortions and the incidence of human immunodeficiency virus seropositivity. J Reprod Med. 1996;41:15-8.

3. Brocklehurst P, French R. The association between maternal HIV infection and perinatal outcome: a systematic review of the literature and meta-analysis. Br J Obstet Gynaecol. 1998;105:836-48.

4. Ryder RW, Nsa W, Hassig SE, Behets F, Rayfield M, Ekungola B, et al. Perinatal transmission of the human immunodeficiency virus type-1 to infants of seropositive women in Zaire. $\mathrm{N}$ Engl $\mathrm{J}$ Med. 1989;320:1637-42.

5. Scarlatti G. Pediatric HIV infection. Lancet. 1996;348:863-8.

6. Temmerman M, Plummer FA, Mirza NB, NdinyaAchola JO, Wamola IA, Nagelkerke $\mathrm{N}$, et al. Infection with HIV as a risk factor for adverse pregnancy outcome. AIDS. 1990;4:139-44.

7. Minkoff HL, Willoughby A, Mendez H, Moroso G, Holman S, Goedert JJ, et al. Serious infections during pregnancy among women with advanced human immunodeficiency virus infection. Am J Obstet Gynecol. 1990;162:30-4.

8. Turner BJ, McKee LJ, Silverman NS, Hauck WW, Fanning TR, Markson LE. Prenatal care and birth outcomes of a cohort of HIV-infected women. J Acquir Immune Defic Syndr Hum Retrovirol. 1996;12:259-67.

9. Turner NJ, Markson L, Hauck W, Cocroft J, Fanning T. Prenatal care of HIV-infected women: analysis of a large New York State cohort. J Acquir Immune Defic Syndr Hum Retrovirol. 1995;9:371-8.

10. NACO guideline HIV testing, 2007. Available at: http://naco.gov.in/upload/Policies\%20\&\%20Guideli 
nes/5-

GUILDELINES\%20FOR\%20HIV\%20TESTING.pd f.

11. NACO Antiretroviral Therapy Guidelines for HIVInfected Adults and Adolescents Including Postexposure Prophylaxis. 2007. Available at: http://naco.gov.in/upload/Policies\%20\&\%20Guideli nes/1.\%20Antiretroviral\%20Therapy\%20Guidelines $\% 20$ for\% $20 \mathrm{HIV}$ -

Infected $\% 20$ Adults $\% 20$ and $\% 20$ Adolescents $\% 20$ Incl uding\%20Post-exposure.pdf.

12. Patel MA, Khatri K, Bharucha KE. Pregnancy outcome in HIV seropositive women. J Obstetric Gynecology India. 2000;50:48.

13. Gnaore E, De Cock KM, Gayle H, Porter A, Coulibaly R, Timite $M$, et al. Prevalence and mortality from HIV Type 2 in Guinea Bissau, West Africa. Lancet. 1989;2:513.

14. D'Ubaldo C, Pezzotti P, Rezza G, Branca M, Ippolito G. Association between HIV-1 infection and miscarriage: a retrospective study. AIDS. 1998;12:1087-93.

15. Shearer WT, Langston C, Lewis DE, Pham EL, Hammill HH, Kozinetz CA, et al. Early spontaneous abortion and fetal thymic abnormalities in maternalto-fetal HIV infection. Acta Pediatr. 1997;421:60-4.

16. Stratton P, Tuomala RE, Abboud R, Rodriguez E, Rich K, Pitt J, et al. Obstetric and newborn outcomes in a cohort of HIV- infected pregnant women: a report of the women and infants transmission study. J Acquir Immune Defic Syndr Hum Retrovirol. 1999;20:179-86.

17. Ellis J, Williams H, Graves W, Lindsay MK. Human immunodeficiency virus infection is a risk factor for adverse perinatal outcome. Am J Obstet Gynecol. 2002;186:903-6.

18. Ezechi OC, Gab-Okafor CV, Oladele DA, Kalejaiye $\mathrm{O}$, Oke B, Ohwodo H, et al. Pregnancy, obstetric and neonatal outcomes in HIV positive nigerian women. Afr J Reprod Health. 2013;17:160-8.

19. Bulterys M, Chao A, Dushimana A, Saah A. Fatal complications after Caesarian section in HIVinfected women. AIDS. 1996;10(8):923-4.

20. Mauri A, Piccione E, Deiana P, Volpe A. Obstetric and perinatal outcome in human immunodeficiency virus-infected pregnant women with and without opiate addiction. Euro J Obstet Gynecol. 1995;58:135-40.

Cite this article as: Desai RS, Shivamurthy G, Desai S. Obstetric and new born outcome in HIV infected pregnant women: a prospective cohort study in Bangalore Medical College Hospitals, India. Int J Reprod Contracept Obstet Gynecol 2018;7:4445-50. 